\title{
Determinants of stock market development: The case of developing countries and Vietnam
}

\author{
SU DINH THANH \\ University of Economics HCMC - dinhthanh@ueh.edu.vn \\ BUI THI MAI HOAI \\ University of Economics HCMC - maihoai@ueh.edu.vn \\ NGUYEN VAN BON \\ University of Economics HCMC - bonvnguyen@yahoo.com
}

ARTICLE INFO ABSTRACT

Article history:

Received:

July 05, 2016

Received in revised form:

Dec. 10, 2016

Accepted:

Dec. 10, 2016

Keywords:

Stock market development

Macroeconomic factor Institutions

Two-way GMM estimation.
Stock market is a key channel to the mobilization of long-term capital in an economy, and determinants of stock market development in developing countries are still undecided. This paper aims to investigate these determinants in Vietnam and other developing countries, whose differences are also pointed out by applying two-way Generalized Method of Moments to the panel data of 36 developing countries over the period of 2003-2014. Our findings are intriguing. First, in developing countries economic growth, domestic credit, and stock market liquidity are positive determinants of the development of stock market. While the effect of money supply is negative, institutional factors such as government effectiveness and rule of law have significantly positive impacts, in contrast to corruption control and political stability (whose impacts are significant and negative). Second, regarding the development of the stock market in Vietnam, the effects of such macroeconomic factors as economic growth, domestic investment, foreign direct investment, domestic credit, broad money supply, stock market liquidity, and inflation are significant and negative, whereas those of all institution variables, including control of corruption, government effectiveness, political stability, regulatory quality, rule of law, and voice and accountability, are significant and positive. This implies that well-established institutions are crucial for promoting a demand for stocks and stock market performance in Vietnam. 


\section{Introduction}

Over two past decades, stock market development has surged as a noteworthy financial channel to raise long-run capital in developing countries. As a result, stock market has a considerable contribution to long-run economic growth. In the literature, the development of stock market is determined by many factors, and several empirical studies have investigated the macroeconomic determinants of stock market development in developing countries (Quartey \& Gaddah, 2007; El-Nader \& Alraimony, 2013; Evrim-Mandaci et al., 2013; Phan \& Vo, 2013; Shahbaz et al, 2015; Acquah-Sam, 2016). However, empirical results are still debatable due to the inconsistency of data and empirical estimators. In addition, there have been very few investigations into the role of institutional quality in determining stock market development.

The Vietnam stock market has developed since early 2000 with the first establishment of stock exchange in Ho Chi Minh City and the later in Hanoi. It has grown sharply during the last decade with regard to the increased number of listed firms and the improved market capitalization and liquidity. Currently, there are over 800 listed firms in the two exchanges. Further growth of the stock market is expected as the Vietnam's government is carrying out policy reforms and restructuring of the market to raise funds in order to meet the demand for long-run capital in Vietnam's industrialization process. However, the literature on determinants of insightful stock market development in Vietnam is still limited.

Our study is motivated by the following reasons. The first motivation is from the huge literature central to the question of whether macroeconomic factors affect the development of stock market (EvrimMandaci et al., 2013; Phan \& Vo, 2013; Shahbaz et al, 2015; Acquah-Sam, 2016). The concerns that institutional quality may result in the development of stock markets are stressed by policy makers, practitioners, and academic researchers. Recent evidence provided by Claessens et al. (2001), Gani \&Ngassam (2008), Yartey (2010), Asongu (2012), and Ayaydin \& Baltaci (2013) supports the argument that institutional quality is crucial to the development of stock market. However, the inconsistency of data and estimators restrains empirical findings. Another is generated from the Vietnamese context. Different aspects of the stock market in Vietnam, as an emerging market where determinants of stock market development are insightfully unidentified, have recently been addressed by a limited number of studies (Batten $\&$ Vo, 2014; Vo, 2015). However, there is still much to be done to identify the effects of institutional quality and macroeconomic factors on its development.

The rest of the paper is structured as follows. Section 2 reviews the literature concerning determinants of stock market development. Section 3 introduces the 
model, method, and data for further empirical analysis. Section 4 presents and discusses the results. Finally, Section 5 concludes the study.

\section{Literature review}

Studies on stock market development can be categorized into three major strands. The first focuses on the macroeconomic determinants of stock market capitalization while the second investigates the effects of institutions on development of stock market, and the third examines the role of FDI inflows in stock market development.

Given the macroeconomic determinants of stock market development, most investigations ascribe the macroeconomic factors such as economic growth, saving rate, investment rate, development of financial intermediaries, and capital market liquidity to the critical determinants of stock market capitalization. Quartey and Gaddah (2007) find that economic growth, credit to private sector, exchange rate, and gross domestic savings have positive effects while interest rate has a negative impact on stock market development in Ghana over the period of 1991-2004, using VECM in addition to Johansen cointegration test. Using the same empirical model as Quartey and Gaddah (2007), El-Nader and Alraimony (2013) conclude that money supply, capital market liquidity, investment rate, inflation, and credit to private sector have positive influence while nominal gross domestic product and net remittances negatively affect stock market development in Jordan from 1990 to 2011. Meanwhile, Evrim-Mandaci et al. (2013) analyze the key determinants of stock market development in 30 advanced and emerging countries during the period between 1960 and pre-financial global meltdown (2007) using random-effect SUR estimation. The results show that credit to private sector, foreign direct investment, and remittances are a few positive determinants of stock market development. Similarly, Phan and Vo (2013), applying the constant coefficients model using pooled OLS for 6 Southeast Asian countries over the period of 1990-2008, recognize economic growth rate, stock market, gross domestic savings, credit to private sector, M2 money supply, and inflation change as key determinants of stock market development. Accordingly, macroeconomic instability (inflation change) has a negative impact while the remaining variables have positive effects on stock market capitalization. Conversely, the empirical results from Shahbaz et al. (2015), which employ VECM with ARDL bounds test, show that inflation has a significantly positive impact on stock market development in Pakistan from 1974 to 2010. Besides inflation, economic growth, investment rate, and credit to private sector have positive effects while trade openness affects negatively stock market development. More recently, using Structural Equation Modeling approach (SEM) for quarterly secondary data spanning from 1991 to 2011 in 
Ghana, Acquah-Sam (2016) provide empirical evidence that the effects of investment rate and economic growth on stock market development are significantly positive while the negative sign is found of interest rates.

In parallel, some studies of this strand also find that financial intermediary development and stock market capitalization are complements instead of substitutes. The estimated results from Garcia and Liu (1999) using FEM confirm that financial intermediary development positively enhances stock market development in 15 industrial and developing countries during the period from 1980 to 1995 . Moreover, economic growth rate, saving rate, investment rate, and stock market liquidity are the positive determinants of stock market development in these countries. With the same methodology and results as Garcia and Liu (1999), Ben Naceur et al. (2007) show that financial intermediaries and stock markets are complements rather than substitutes in the growth process in 12 Middle Eastern and North African (MENA) countries from 1979 to 1999. In addition, Ben Naceur et al. (2007) also verify that saving rate, credit to private sector, stock market liquidity, and inflation change are significant determinants of stock market development. Meanwhile, Cherif and Gazdar (2010) improve the methodology in treating the endogenous phenomena between variables. Through the methods of IV-fixed effects and IVrandom effects, these authors conclude that the relationship between financial intermediaries and stock markets is complementary in 14 MENA countries during 1990-2007. Also, economic growth, savings rate, credit to private sector, stock market liquidity, and interest rate have significant influences on stock market development.

The similarities in the above-mentioned studies lie in policy implications. According to these authors, in order to promote the stock market development, governments should encourage domestic savings, improve capital market liquidity, develop financial intermediaries, and control inflation.

Unlike the above-mentioned investigations, research on the role of institutions in stock market development has recently been carried out. Using estimation methods of GLS, fixed effects, and fixed effects corrected for AR(1) errors for a sample of eight Asian countries during 1996-2005, Gani and Ngassam (2008) detect rule of law and political stability with their positive effects while poor regulatory quality and government effectiveness have negative impacts on stock market development. Moreover, economic growth and technology diffusion are the positive determinants of stock market capitalization. These authors emphasize the prominent role of institutional quality in improving the market performance. Similarly, Yartey (2010) shows institutional factors such as political risk, law and order, democratic accountability, and bureaucratic quality promote 
stock market development via enhancing the viability of external finance using difference panel GMM Arellano-Bond estimator for a panel dataset of 42 emerging economies for the period between 1990 and 2004. In addition, some macroeconomic factors (economic growth, credit to the private sector, gross domestic investment, stock market liquidity) have significantly positive influences on stock market development. Meanwhile, Asongu (2012) argue that the quality of government institutions favorably affects stock market performance for a panel of 14 African countries from 1990 to 2010 by using instrumental variable estimation technique. These findings demonstrate countries with better government institutional environment will favor stock markets with higher value in shares traded, higher market capitalization, better turnover ratios, and the greater number of listed companies.

FDI is regarded as one of the critical sources to economic growth and development in countries worldwide. As regards the role of FDI inflows in stock market development, nearly all papers except for Raza and Jawaid (2014) find that FDI significantly improves stock market development. Claessens et al. (2001) describe FDI as a complement, not a substitute for domestic stock market development for a sample of 77 countries in the 1975-2000 period, whereas Jeffus (2004) indicates that the impact of FDI inflows on stock market development is significantly positive in four Latin American countries for the period of 1988-2002. Similarly, Raza et al. (2012) conclude FDI inflows foster stock market development in Pakistan over the period of 1988-2009 using OLS estimation. Meanwhile, Abdul Malik \& Amjad (2013), adopting Johansen co-integration approach, provide empirical evidence to support the hypothesis of the positive role of FDI inflows in boosting stock market development in Pakistan during 1985-2011. Recently, Raza et al. (2015) employ ARDL bound testing cointegration, DOLS, and FMOLS techniques for analyzing the annual time series data of Pakistan from 1976 to 2011, also finding that FDI has a positive impact on stock market capitalization in both long and short terms. Conversely, the estimated results from Raza and Jawaid (2014) demonstrate that FDI has a significantly negative effect on the stock market capitalization in both the long and short run by applying the VECM technique with ARDL bound test for 18 Asian countries over the period of 2000-2010.

Apart from institutional quality, corruption, democracy, and trust are also different measures of institutions. Ayaydin and Baltaci (2013) confirm the negative impact of corruption yet the positive effect of banking sector development on stock market development for a panel of 42 emerging economies between 1996 and 2011 applying fixed effects estimation. Their empirical findings attribute some macroeconomic factors such as credit to 
private sector, inflation rate, money supply, economic growth rate, gross savings, FDI inflows, and real interest rate to significant determinants of stock market development. Recently, by applying the random effects GLS method for a sample of 22 African countries from 1985 through 2011, Biswas and Ofori (2015) explore the contribution of democracy and constitutional limits on the number of years a chief executive allowed to serve to significantly improved stock market development. Far more lately, $\mathrm{Ng}$ et al. (2016) use the relevance of social capital in stock market development as a proxy for social institutions (trust). Through Bayesian model averaging (BMA) applied to 37 variables across 60 countries from 2000 to 2006, they find that trust is a positive determinant of stock market development and the most relevant component of social capital in market development. Macroeconomic instability (inflationary changes) has an adverse impact on trust in the trading of stock. Moreover, their estimated outcomes illustrate the association between social capitals, particularly trust, and market development in affluent countries with lower formal institutional environment.

In short, alongside different perspectives as found with existing literature, so far there has been little use of the system panel GMM Arellano-Bond in investigating the effects of macroeconomic factors, FDI, and institutions on stock market development for a large sample of develop- ing countries alone. This is also the research gap to be significantly filled.

The estimates of panel macro-dataset are often biased due to endogenous phenomenon and serial autocorrelation. The estimation methods of fixed effects and random effects cannot solve these problems, especially heteroskedasticity while the PMG (pool mean group) and $\mathrm{MG}$ (mean group) estimators, two typical kinds of ARDL (autoregressive distributed lags) estimators for panel data, require a relatively long-time dimension to estimate the effects of regressors in both long and short terms. Meanwhile, the IV-2SLS estimator needs some instrumental variables out of regressors to solve the problem of endogeneity. In particular, through the Monte Carlo approach, Judson and Owen (1999) assessed the degree of bias among OLS, LSDV (least squares dummy variable), adjusted-LSDV, Anderson-Hsiao estimator, and GMM Arellano-Bond estimator. In conclusion, Judson and Owen (1999) suggested that it is better to use GMM Arellano-Bond estimator for a panel with a short-time dimension as is employed in our study.

\section{Empirical model, research method, and data}

\subsection{Empirical model}

Based on the study of Yartey (2008), this study uses the following equation to explore determinants of stock market development in developing countries: 
$C A P_{i t}=\alpha_{0}+\alpha_{1} C A P_{i t-1}+\alpha_{2} X_{i t}+\eta_{i}+\zeta_{i t}$

This basic model is modified to test for the case of Vietnam:

$$
\begin{aligned}
& C A P_{i t}=\beta_{0}+\beta_{1} C A P_{i t-1}+\beta_{2} X_{i t} \\
& +\beta_{3} v n_{-} X_{i t}+\eta_{i}+\zeta_{i t}
\end{aligned}
$$

where $i$ is for countries, $t$ is for time period; $\eta_{i} \sim \operatorname{iid}\left(0, \sigma_{\eta}\right) ; \zeta_{i t} \sim \operatorname{iid}\left(0, \sigma_{\zeta}\right) ; E\left(\eta_{i} \zeta_{i t}\right)=0$. $v n_{-} X$ is a set of variables that is formulated by interaction between dummy variable $(D)$ for Vietnam and $\mathrm{X}$ variables; $D=1$ if $i$ is Vietnam, otherwise $D=0 . \mathrm{X}$ is a set of macroeconomic determinants of stock market development, which is selected as follows:

\section{Economic growth (real GDP per cap-} ita) (GDP): Garcia and Liu (1999) and Yartey (2010) note that the real income per capita is positively associated with stock market size. Via the stock market some factors can promote the real income. High income growth in turn enhances stock market development.

Gross domestic savings and investment (INV): Garcia and Liu (1999) argue that like financial intermediaries, stock markets will mobilize savings toward investment projects. The larger the savings, the higher the amount of investment capital is mobilized via stock markets.

Foreign direct investment inflows (FDI): FDI inflows and stock market development can be complements or substitutes. Claessens et al. (2001), Jeffus (2004), Raza et al. (2012), Abdul Malik and Amjad (2013), and Raza et al. (2015) suggest that FDI has a positive impact on stock market development while Raza and Jawaid (2014) find the negative influence of FDI.

\section{Financial intermediary development:} This is likely to be defined by domestic credit to private sector (CRE) and broad money supply (MO2). According to Garcia and Liu (1999), the banking sector and stock markets can be either substitutes or complements because they both mobilize gross domestic savings toward different investment projects.

Stock market liquidity (LIQ): Liquidity is one of the main functions, which stock markets provide. Many high profit investment projects need a long-run commitment of capital, which leads to high default and liquidity risks (Garcia \& Liu, 1999). Thus, liquid stock markets help investors change their portfolios quickly and with low costs, making investment less risky and more profitable. Consequently, the more liquid the stock market, the larger amount of savings could be raised.

Macroeconomic stability: This is measured by inflation (INF). Macroeconomic stability can contribute importantly to stock market development. Garcia and Liu (1999) argue that higher volatility of the economic situation is attributed to less participation of incentive firms and savers in the stock market. In an instable macroeconomic environment, it is hard to predict price changes, and thus the stock market becomes more uncertain. 
Institutional quality: Pagano (1993) document that regulations and institutions also affect the efficiency of stock market. Disclosure of information about the business from firms is supposed to attract investors to participate in the capital market and enhance the capital market development.

\subsection{Research method}

This study applies two-step system Generalized Methods of Moments (GMM) to estimate Eq.1a and Eq.1b. Indeed, in estimating Eq.1a and Eq.1b there is a serious difficulty that arises with fixed effects model in the context of a dynamic panel with a lagged dependent variable $\left(C A P_{i t-1}\right)$. Since $C A P_{i t-1}$ is a function of $C A P$, $C A P_{i t-1}$ is correlated with the error term. This is because with a technical consequence of the within transformation $N$, the lagged dependent variable $\left(C A P_{i t-1}\right)$ increase standard errors. The resulting correlation creates a large-sample bias involved in estimating the coefficient of the lagged dependent variable, which may be not mitigated by increasing $N$ (Nickell, 1981). If the regressors are correlated with the lagged dependent variable to some degree, their coefficients may be seriously biased. Moreover, it is especially problematic in the case of data with a small time dimension. Cross-section estimates would produce a bias caused by the correlation between the lagged dependent variable and the unobserved individual effects as the present value of the dependent variable itself would be dependent on the individual effects, which may disappear in samples with large time dimension. An alternative is to use any type of fixed effect technique, eliminating time-independent effects by taking some kind of difference (e.g., first differences, within group transformations, etc.). By taking first differences, the fixed individual effect is removed because it does not vary over time. In this case, however, the error term would have some lags and therefore will be correlated with the lagged dependent variable, leading to biased estimates. Several methods have been proposed in earlier literature (e.g., Anderson \& Hsiao, 1982; Arellano \& Bond, 1991; Blundell \& Bond, 1998).

Arellano and Bond (1991) propose that difference GMM estimator is more efficient than the Anderson \& Hsiao's (1982) estimator. GMM estimator deals better with endogneity, heteroskedasticity, and serial correction because it is specifically designed to capture the joint endogeneity of some explanatory variables through the creation of a weight matrix of internal instruments, which accounts for serial correlation and heteroscedasticity. GMM estimator requires one set of instruments to handle endogeneity and another set to deal with the correlation between lagged dependent variable and the error term. The instruments include suitable lags of the endogenous variables and the strictly exogenous regressors. This estimator technique easily generates many instruments, since 
by period $T$ all prior lags might be individually considered instruments. However, a big problem of the Arellano-Bond difference GMM estimator lies in the fact that the variance of the estimates could increase asymptotically and create considerable bias. Blundell and Bond (1998) and Blundell et al. (2001) show that estimation in first differences has a large bias and low precision, even in studies with large number of individuals $(\mathrm{N})$. The system GMM estimator is likely to exhibit the best features in terms of small samples. Provided that series are moderately or highly persistent, system GMM estimator will display the lowest bias and highest precision (Soto, 2009).

The system GMM estimator requires moment conditions, which are specified on the regression errors. The moment conditions assumption is that instruments are exogenous. For this, the moments of the errors with instruments are equal to zero. In system GMM estimator, the choice of instruments and regressors in each equation should be carefully considered. Since an equation may be under-identified, exactly identified, and over-identified depending on whether the number of instruments in that equation are respectively less than, equal to, or greater than that of the regressors to be estimated. For the twostep system GMM, this estimator is more asymptotically efficient than the one-step estimator due to using a suboptimal weighting matrix, but it produces the bias of uncorrected standard errors when instrument count is high. In this respect, Roodman (2009) provides a rule of thumb that the number of instruments should be less than that of individual dimensions $(\mathrm{N})$.

In system GMM estimation, Sargan and Hansen tests have a null hypothesis that "the instruments are exogenous." Therefore, the higher the $p$-value of Sargan and Hansen statistic, the better it is to accept this null hypothesis. The ArellanoBond test for autocorrelation has a null hypothesis of no autocorrelation, and therefore is applied to differenced error terms. The test for $\mathrm{AR}(2)$ process in first differences usually rejects the null hypothesis. The test for $\operatorname{AR}(2)$ is more material, since it detects autocorrelation in levels.

\subsection{Data}

Cross-sections and time series are extracted to accommodate the unbalanced panel data of 36 developing countries (20 in Asia $^{1}, 10$ in Latin America ${ }^{2}$, and 6 in Africa $^{3}$ ) over the period of 2003-2014 from World Development Indicator of World Bank and World Economic Outlook of International Monetary Fund. Some missing values of the data set in some countries are filled with reference to

${ }^{2}$ Argentina, Bolivia, Brazil, Chile, Colombia, Costa Rica, El Salvador, Mexico, Panama, and Peru

${ }^{3}$ Egypt, Ghana, Kenya, Mauritius, Nambia, and Nigeria 
www.tradingeconomics.com and www.indexmundi.com. We define and calculate the variables as follows:

CAP: stock market capitalization as a proxy for development of stock market (\% of GDP)

GDP: real GDP per capita, a proxy for economic growth of a country (this variable is used in the form of natural logarithm)

INV: domestic investment (\% of GDP)

FDI: foreign direct investment, net inflows (\% of GDP)

CRE: domestic credit to private sector (\% of GDP)

MO2: money and quasi money (M2) (\% of GDP)

LIQ: stocks traded, total value (\% of GDP)

INFL: inflation per year (\%)

Institutional Quality: including six governance indicators of World Bank, defined as follows:

Control of Corruption (IN1) measures the perceptions of the extent to which public power is exercised for private gain.

Government Effectiveness (IN2) refers to the perceptions of the effectiveness of public services and civil service and the level of its independence from political pressures, the effectiveness of policy formulation and implementation, and the credibility of the government's commitment to such policies.
Political Stability and Absence of Violence/Terrorism (IN3) captures the perceptions of the probability of political instability and/or politically motivated violence, which includes terrorism.

Regulatory Quality (IN4) measures the perceptions of the competence of the government to design, formulate, and implement sound policies and regulations that foster the development of private sector.

Rule of Law (IN5) is defined as the perceptions of the extent to which agents comply with the rules of society, and in particular the quality of contract enforcement, property rights, the police, and the court.

Voice and Accountability (IN6) constitutes the perceptions of the extent to which citizens of a country have rights to select their government, as well as freedom of expression, freedom of association, and freedom of the media.

The estimates of these indicators allow the country's score to be given on the aggregate indicator, ranging between approximately -2.5 and 2.5 .

The statistical values are years of 1996 , 1998, and 2000, and from 2002 to 2014. Missing values (1997, 1999, and 2001) are filled by the sum of average value of preceding and following years. Statistical description of all variables is presented in Table 1. 
The 36 countries in the research sample are characterized as developing countries that experience a relatively short period of capital market development. In particular, the quality of the institutional environment in these countries is low. The distinctive features among these countries are culture, manners and customs, geography, and demography. In the empirical model, these features are contained in $\eta_{i}$ (unobserved time-invariant, country-specific effect). The two-step system GMM definitely removes $\eta_{i}$ in the estimation procedure (see more in Sub-Section 3.2).

\section{Results and discussion}

4.1. Macroeconomic determinants of stock market development

Table 2 reports initial estimated results without institutions. Model 3 is baseline regression that includes macroeconomic determinants of stock market development, such as economic growth (GDP), domestic investment (INV), foreign direct investment (FDI), domestic credit (CRE), M2 money supply (MO2), stock market liquidity (LIQ). Our findings are interesting. First, domestic investment and FDI both have no significant effects on stock market

\section{Table 1}

Statistical description

\begin{tabular}{lccccc}
\hline Variables & Obs. & Mean & Std. dev. & Min & Max \\
\hline Stock market capitalization (CAP) & 432 & 46.263 & 37.369 & 0.360 & 196.71 \\
Log GDP per capita (GDP) & 432 & 8.142 & 1.220 & 5.709 & 11.037 \\
Domestic investment (INV) & 432 & 23.779 & 7.992 & 5.458 & 73.600 \\
Foreign direct investment (FDI) & 432 & 3.861 & 4.227 & -4.377 & 45.273 \\
Domestic credit (CRE) & 432 & 50.386 & 30.136 & 2.700 & 146.746 \\
M2 money supply (MO2) & 432 & 65.275 & 43.712 & 0.500 & 255.46 \\
Stock market liquidity (LIQ) & 432 & 19.238 & 36.917 & 0.008 & 372.25 \\
Inflation (INF) & 432 & 6.062 & 5.093 & -4.863 & 39.226 \\
Control of Corruption (IN1) & 432 & -0.208 & 0.616 & -1.320 & 1.722 \\
Government Effectiveness (IN2) & 432 & -0.020 & 0.531 & -1.200 & 1.477 \\
Political Stability (IN3) & 432 & -0.413 & 0.936 & -2.812 & 1.210 \\
Regulatory Quality (IN4) & 432 & -0.015 & 0.578 & -1.730 & 1.536 \\
Rule of Law (IN5) & 432 & -0.176 & 0.614 & -1.522 & 1.426 \\
Voice and Accountability (IN6) & 432 & -0.318 & 0.731 & -1.862 & 1.244 \\
\hline
\end{tabular}


development, while their positive effects are found by Garcia and Liu (1999), Claessens et al. (2001), Jeffus (2004), Yartey (2010), Raza et al. (2012), Abdul Malik and Amjad (2013), Ayaydin and Baltacı (2013), El-Nader and Alraimony (2013), Evrim-Mandaci et al. (2013), Raza et al. (2015), Shahbaz et al. (2015), and Acquah-Sam (2016). Second, the significant and positive coefficient of GDP shows that higher growth rates in developing countries can be associated with higher development of stock market, which is similar to findings from earlier studies (Garcia \& Liu, 1999; Claessens et al., 2001; Quartey \& Gaddah, 2007; Gani \& Ngassam, 2008; Yartey, 2010; Ayaydın \& Baltacı, 2013; Phan \& Vo, 2013; Raza \& Jawaid, 2014; Raza et al., 2015; Shahbaz et al., 2015; Acquah-Sam, 2016). Economic growth results from high household savings rates and increased labor force participation, as well as technological innovation. Increased demand for production inputs (capital, labor, technology) arises for newly established enterprises, leading to an increase in stock market capitalization. Third, the coefficient of domestic credit is significantly positive, as supported by Garcia and Liu (1999), Yartey (2010), El-Nader and Alraimony (2013), and Shahbaz et al. (2015). This result shows that a higher level of domestic credit to private sector (CRE) is related to higher growth of stock market capitalization, which implies that there exists a complementary relation between the banking sector and the stock market in developing countries. In fact, in developing countries capital demand could rise, whereas their banking sector's development is not healthy enough to satisfy this need. Thus, the private sector in developing countries is also to rely on funding from the stock market, which in turn also needs funding for investment projects. Fourth, broad money supply (MO2) has a significantly negative effect on stock market capitalization, which is opposite to the findings of Garcia and Liu (1999), Cherif and Gazdar (2010), Ayaydın and Baltacı (2013), ElNader and Alraimony (2013), and Phan and Vo (2013). The negative association between broad money supply and stock market capitalization implies that a positive money supply shock will lead a decrease in interest rate. As the interest rate declines, enterprises will seek additional borrowings from financial institutions due to their lower costs, causing a decline in stock market capitalization. This shows that developing countries rely heavily on financial sectors to provide credit for economic activities since their stock market capitalizations are still quite small in comparison with capital demand. Fifth, the coefficient of stock market liquidity is significantly positive, which is in agreement with Garcia and Liu (1999), Ben Naceur et al. (2007), Cherif and Gazdar (2010), Yartey (2010), El-Nader and Alraimony (2013), and Phan and Vo (2013). Indeed, the more liquid the stock market, the larger amount of savings would flow to it. Finally, the effect of inflation on stock mar- 
ket capitalization is negative and significant, as agreed by Claessens et al. (2001), Ben Naceur et al. (2007), Ayaydın and Baltac1 (2013), and Phan and Vo (2013). Macroeconomic stability measured by inflation is also a contributory factor to stock market development. Increased inflation leads to macroeconomic volatility; as a result, firms and investors have no more incentives to participate in the stock market.

\subsection{Institutional quality and stock mar- ket development}

In this sub-section, we estimate the effects of components of institutional quality on stock market development. Table 3 shows the estimated results, where the effects of economic growth (GDP), domestic investment (INV), foreign direct investment (FDI), domestic credit (CRE), M2 money supply (MO2), stock market liquidity (LIQ), and inflation (INF) are very consistent in all estimators. Our findings provide novel empirical evidence of the impact of institutional quality on stock market development. In Model 1 the coefficient of control of corruption (IN1) is significantly negative, which is different from the studies of Gani and Ngassam (2008), Yartey (2010), and Asongu (2012). This shows that an improvement in control of corruption may cause investors' reduced required return on equity and risk premium. Our result is in support of the idea that corruption is likely to be a necessary lubricant to spur stock market development in developing countries. As ar- gued by Swaleheen (2011) and Dzhumashev (2014), corruption may facilitate growth by helping firms sidestep burdensome public policies. In Model 2 we measure the effect of government effectiveness (IN2) on stock market development. Effective government, which enhances the quality of policy formulation and implementation and the credibility of the government's commitment to such policies, should be positively related to stock market development. This result reinforces the idea that government effectiveness significantly and positively affects stock market development. In Model 3 the effect of political stability (IN3) on stock market development is tested. The result shows that the coefficient of political stability is significantly negative, which is in line with the study of Goldsmith (1987) to shed light on Mancur Olson's theory of political stability and growth. In Model 4 we look at the effect of regulatory quality (IN4) on stock market development. Regulatory quality displays the capacity of government in formulating and carrying out sound policies and regulations to promote private sector development, and therefore it should be positively associated with stock market development. However, the result suggests that regulatory quality exerts a statistically insignificant and positive effect on stock market development in developing countries. In Model 5 we examine the relation of rule of law (IN5) with stock market development, finding that it is significant and positive. This im- 
plies that the rule of law is another deter- that its improvement causes a reduction in minant of stock market development and

\section{Table 2}

Macroeconomic determinants of stock market development: The case of developing countries

Dependent variable: Stock market capitalization (\% of GDP)

\begin{tabular}{|c|c|c|c|}
\hline & Model 1 & Model 2 & Model 3 \\
\hline \multirow[t]{2}{*}{ Stock market capitalization $(-1)$} & $0.533 * * *$ & $0.631 * * *$ & $0.440 * * *$ \\
\hline & $(0.063)$ & $(0.056)$ & $(0.043)$ \\
\hline \multirow[t]{2}{*}{ Log GDP per capita } & $9.106 * * *$ & $4.888 * *$ & $1.702^{*}$ \\
\hline & $(0.904)$ & $(0.784)$ & $(0.867)$ \\
\hline \multirow[t]{2}{*}{ Domestic investment } & -0.098 & -0.024 & 0.027 \\
\hline & $(0.106)$ & $(0.098)$ & $(0.070)$ \\
\hline \multirow[t]{2}{*}{ Foreign direct investment } & & -0.168 & -0.113 \\
\hline & & $(0.147)$ & $(0.145)$ \\
\hline \multirow[t]{2}{*}{ Domestic credit } & & & $0.332 * * *$ \\
\hline & & & $(0.062)$ \\
\hline \multirow[t]{2}{*}{ M2 money supply } & & & $-0.205 * * *$ \\
\hline & & & $(0.053)$ \\
\hline \multirow[t]{2}{*}{ Stock market liquidity } & & & $0.250 * * *$ \\
\hline & & & $(0.019)$ \\
\hline \multirow[t]{2}{*}{ Inflation } & & & $-1.269 * * *$ \\
\hline & & & $(0.113)$ \\
\hline \multirow[t]{2}{*}{ Constant } & $-51.046 * * *$ & $-23.965 * * *$ & $12.633^{*}$ \\
\hline & $(6.465)$ & $(6.225)$ & $(7.253)$ \\
\hline Obs. & 396 & 396 & 396 \\
\hline No. of instruments & 20 & 22 & 33 \\
\hline No. of groups & 36 & 36 & 36 \\
\hline $\mathrm{AR}(2)$ test & 0.146 & 0.132 & 0.217 \\
\hline Sargan test & 0.354 & 0.124 & 0.292 \\
\hline Hansen test & 0.156 & 0.186 & 0.135 \\
\hline
\end{tabular}


stock market risks, facilitating more investment in equity and higher returns in developing countries. In Model 6, the effect of voice and accountability (IN6) on stock market development is investigated. The result indicates that the coefficient of voice and accountability is positive yet statistically insignificant, implying that improvement in voice and accountability is not attributed to any improvement in stock market performance in developing countries.

\subsection{Determinants of stock market devel- opment in Vietnam}

In this part we first explore macroeconomic determinants of stock market development in Vietnam. We generate a dummy variable for Vietnam, and then inspect the interactions between the Vietnam dummy with macroeconomic variables such as economic growth (GDP), domestic investment (INV), foreign direct investment (FDI), domestic credit (CRE), M2 money supply (MO2), stock market liquidity (LIQ), and inflation (INF). These interactions create six new variables, including vnD_lgdp, vnD_inv, vnD_fdi, vnD_cre, vnD_mo2, vnD_liq, and vnD_inf. We estimate six models by turns with each regression having one of the six variables (see Eq. 1b). The estimated results presented in Table 4 show that macroeconomic determinants of stock market development in Vietnam are different from those in developing countries. All macroeconomic factors have significantly negative effect on the development of stock market in Vietnam. In Model 1 we look at the effect of economic growth (GDP) on stock market development in Vietnam. The significantly negative coefficient of economic growth implies that an improvement in economic growth cannot be contributing to stock market development in Vietnam. This result underpins Vo et al.'s (2016) findings. In Models 2 and 3 we examine the role of private investment (domestic and foreign direct investment) in determining stock market development in Vietnam. The results demonstrate that the effects of domestic and foreign direct investment are significant and negative in explaining stock market development in Vietnam. Models 4 and 5 illustrate the impact of financial intermediary development (including domestic credit and M2 money supply) on stock market development in Vietnam. High levels of financial intermediary development relate significantly and negatively to Vietnam's stock market development. This result is inconsistent with Anwar and Nguyen (2011). In Model 6 the effect of stock market liquidity on stock market development is captured for the case of Vietnam. Since the coefficient of stock market liquidity is significant and negative, an increase in stock market liquidity cannot improve stock market development in the country. Model 7 highlights the impact of inflation on stock market development, demonstrating its significant and negative association with the development of stock market in Vietnam. 


\section{Table 3}

The effects of institutional quality on stock market development: The case of developing countries

Dependent variable: Stock market capitalization (\% of GDP)

\begin{tabular}{|c|c|c|c|c|c|c|}
\hline & $\begin{array}{l}\text { Model } 1 \\
\text { (IN1) }\end{array}$ & $\begin{array}{l}\text { Model } 2 \\
\text { (IN2) }\end{array}$ & $\begin{array}{l}\text { Model } 3 \\
\text { (IN3) }\end{array}$ & $\begin{array}{l}\text { Model } 4 \\
\text { (IN4) }\end{array}$ & $\begin{array}{l}\text { Model } 5 \\
\text { (IN5) }\end{array}$ & $\begin{array}{l}\text { Model } 6 \\
\text { (IN6) }\end{array}$ \\
\hline Stock market capital. (-1) & $\begin{array}{l}0.466^{* * *} \\
(0.042)\end{array}$ & $\begin{array}{l}0.566^{* * *} \\
(0.033)\end{array}$ & $\begin{array}{l}0.467^{* * *} \\
(0.066)\end{array}$ & $\begin{array}{l}0.455^{* * *} \\
(0.043)\end{array}$ & $\begin{array}{l}0.551^{* * *} \\
(0.033)\end{array}$ & $\begin{array}{l}0.341^{* * *} \\
(0.035)\end{array}$ \\
\hline Log GDP per capita & $\begin{array}{l}2.644^{* *} \\
(1.034)\end{array}$ & $\begin{array}{l}2.567^{* * *} \\
(0.665)\end{array}$ & $\begin{array}{l}4.470^{* * *} \\
(1.409)\end{array}$ & $\begin{array}{l}1.619^{*} \\
(0.839)\end{array}$ & $\begin{array}{l}3.866^{* * *} \\
(0.419)\end{array}$ & $\begin{array}{l}2.487^{* * *} \\
(0.677)\end{array}$ \\
\hline Domestic investment & $\begin{array}{l}-0.005 \\
(0.081)\end{array}$ & $\begin{array}{l}-0.074 \\
(0.046)\end{array}$ & $\begin{array}{l}-0.003 \\
(0.072)\end{array}$ & $\begin{array}{l}-0.103 \\
(0.077)\end{array}$ & $\begin{array}{l}-0.140^{* * *} \\
(0.040)\end{array}$ & $\begin{array}{l}-0.074 \\
(0.116)\end{array}$ \\
\hline $\begin{array}{l}\text { Foreign direct invest- } \\
\text { ment }\end{array}$ & $\begin{array}{l}-0.039 \\
(0.164)\end{array}$ & $\begin{array}{l}-0.169 \\
(0.129)\end{array}$ & $\begin{array}{l}0.111 \\
(0.400)\end{array}$ & $\begin{array}{l}-0.035 \\
(0.131)\end{array}$ & $\begin{array}{l}-0.164 \\
(0.126)\end{array}$ & $\begin{array}{l}-0.111 \\
(0.192)\end{array}$ \\
\hline Domestic credit & $\begin{array}{l}0.464^{* * *} \\
(0.068)\end{array}$ & $\begin{array}{l}0.117^{* * *} \\
(0.029)\end{array}$ & $\begin{array}{l}0.316^{* * *} \\
(0.113)\end{array}$ & $\begin{array}{l}0.371^{* * *} \\
(0.060)\end{array}$ & $\begin{array}{l}0.200^{* * *} \\
(0.040)\end{array}$ & $\begin{array}{l}0.526^{* * *} \\
(0.090)\end{array}$ \\
\hline M2 money supply & $\begin{array}{l}-0.294^{* * *} \\
(0.060)\end{array}$ & $\begin{array}{l}-0.069^{* * *} \\
(0.024)\end{array}$ & $\begin{array}{l}-0.198^{* *} \\
(0.089)\end{array}$ & $\begin{array}{l}-0.226^{* * *} \\
(0.054)\end{array}$ & $\begin{array}{l}-0.106^{* * *} \\
(0.030)\end{array}$ & $\begin{array}{l}-0.410^{* * *} \\
(0.074)\end{array}$ \\
\hline Stock market liquidity & $\begin{array}{l}0.191^{* * *} \\
(0.037)\end{array}$ & $\begin{array}{l}0.166^{* * *} \\
(0.172)\end{array}$ & $\begin{array}{l}0.232^{* * *} \\
(0.022)\end{array}$ & $\begin{array}{l}0.223^{* * *} \\
(0.031)\end{array}$ & $\begin{array}{l}0.039^{* * *} \\
(0.017)\end{array}$ & $\begin{array}{l}0.303^{* * *} \\
(0.026)\end{array}$ \\
\hline Inflation & $\begin{array}{l}-1.229^{* * *} \\
(0.139)\end{array}$ & $\begin{array}{l}-0.853^{* * *} \\
(1.612)\end{array}$ & $\begin{array}{l}-1.007^{* * *} \\
(0.243)\end{array}$ & $\begin{array}{l}-1.153^{* * *} \\
(0.125)\end{array}$ & $\begin{array}{l}-0.835^{* * *} \\
(0.093)\end{array}$ & $\begin{array}{l}-1.182^{* * *} \\
(0.095)\end{array}$ \\
\hline Institutional quality & $\begin{array}{l}-4.917^{* *} \\
(2.386)\end{array}$ & $\begin{array}{l}4.056^{* *} \\
(1.612)\end{array}$ & $\begin{array}{l}-6.720^{* *} \\
(2.625)\end{array}$ & $\begin{array}{l}1.117 \\
(2.068)\end{array}$ & $\begin{array}{l}3.733^{* * *} \\
(1.120)\end{array}$ & $\begin{array}{l}0.064 \\
(2.122)\end{array}$ \\
\hline Constant & $\begin{array}{l}1.861 \\
(9.069)\end{array}$ & $\begin{array}{l}2.866 \\
(5.348)\end{array}$ & $\begin{array}{l}-16.384 \\
(13.547)\end{array}$ & $\begin{array}{l}13.843 \\
(8.258)\end{array}$ & $\begin{array}{l}-4.764 \\
(4.052)\end{array}$ & $\begin{array}{l}14.029^{* *} \\
(5.906)\end{array}$ \\
\hline Obs. & 360 & 396 & 396 & 360 & 396 & 396 \\
\hline No. of instruments & 32 & 36 & 27 & 32 & 36 & 35 \\
\hline No. of groups & 36 & 36 & 36 & 36 & 36 & 36 \\
\hline
\end{tabular}




\begin{tabular}{lcccccc}
\hline AR(2) test & 0.178 & 0.173 & 0.174 & 0.195 & 0.205 & 0.271 \\
\hline Sargan test & 0.290 & 0.102 & 0.366 & 0.241 & 0.545 & 0.102 \\
\hline Hansen test & 0.289 & 0.218 & 0.158 & 0.256 & 0.204 & 0.258 \\
\hline
\end{tabular}

Notes: $* * *, * *$ and $*$ denote significance at $1 \%, 5 \%$, and $10 \%$ respectively; standard deviation is in parentheses.

\section{Table 4}

Macroeconomic determinants of stock market development in Vietnam

Dependent variable: Stock market capitalization (\% of GDP)

\begin{tabular}{|c|c|c|c|c|c|c|c|}
\hline & $\begin{array}{c}\text { Model } 1 \\
\text { (vnD_gdp) }\end{array}$ & $\begin{array}{l}\text { Model } 2 \\
\text { (vnD_inv) }\end{array}$ & $\begin{array}{l}\text { Model } 3 \\
\text { (vnD_fdi) }\end{array}$ & $\begin{array}{c}\text { Model } 4 \\
\text { (vnD_mo2) }\end{array}$ & $\begin{array}{l}\text { Model } 5 \\
\text { (vnD_cre) }\end{array}$ & $\begin{array}{l}\text { Model } 6 \\
\text { (vnD_liq) }\end{array}$ & $\begin{array}{l}\text { Model } 7 \\
\text { (vnD_inf) }\end{array}$ \\
\hline $\begin{array}{l}\text { Stock market } \\
\text { capital. (-1) }\end{array}$ & $\begin{array}{l}0.389^{* * * *} \\
(0.041)\end{array}$ & $\begin{array}{l}0.346^{* * *} \\
(0.039)\end{array}$ & $\begin{array}{l}0.360^{* * *} \\
(0.040)\end{array}$ & $\begin{array}{l}0.328^{* * *} \\
(0.041)\end{array}$ & $\begin{array}{l}0.327^{* * *} \\
(0.039)\end{array}$ & $\begin{array}{l}0.376^{* * *} \\
(0.041)\end{array}$ & $\begin{array}{l}0.395^{* * *} \\
(0.042)\end{array}$ \\
\hline $\begin{array}{l}\text { Log GDP per } \\
\text { capita }\end{array}$ & $\begin{array}{l}1.790^{*} \\
(0.960)\end{array}$ & $\begin{array}{l}2.594^{* *} \\
(1.013)\end{array}$ & $\begin{array}{l}2.422^{* *} \\
(1.021)\end{array}$ & $\begin{array}{l}2.818^{* *} \\
(1.118)\end{array}$ & $\begin{array}{c}2.896^{* * *} \\
(1.066)\end{array}$ & $\begin{array}{l}2.429^{* *} \\
(0.946)\end{array}$ & $\begin{array}{l}2.207^{* *} \\
(0.876)\end{array}$ \\
\hline $\begin{array}{l}\text { Domestic in- } \\
\text { vestment }\end{array}$ & $\begin{array}{l}0.024 \\
(.069)\end{array}$ & $\begin{array}{l}-0.029 \\
(0.069)\end{array}$ & $\begin{array}{l}-0.017 \\
(0.074)\end{array}$ & $\begin{array}{l}-0.043 \\
(0.077)\end{array}$ & $\begin{array}{l}-0.050 \\
(0.074)\end{array}$ & $\begin{array}{l}-0.022 \\
(0.067)\end{array}$ & $\begin{array}{l}-0.003 \\
(0.071)\end{array}$ \\
\hline $\begin{array}{l}\text { Foreign direct } \\
\text { investment }\end{array}$ & $\begin{array}{l}-0.027 \\
(0.143)\end{array}$ & $\begin{array}{l}-0.031 \\
(0.165)\end{array}$ & $\begin{array}{l}-0.040 \\
(0.164)\end{array}$ & $\begin{array}{l}-0.016 \\
(0.170)\end{array}$ & $\begin{array}{l}0.0005 \\
(0.171)\end{array}$ & $\begin{array}{l}-0.032 \\
(0.155)\end{array}$ & $\begin{array}{l}-0.098 \\
(0.164)\end{array}$ \\
\hline $\begin{array}{l}\text { Domestic } \\
\text { credit }\end{array}$ & $\begin{array}{l}0.333^{* * *} \\
(0.065)\end{array}$ & $\begin{array}{l}0.425^{* * *} \\
(0.067)\end{array}$ & $\begin{array}{l}0.421^{\text {*** }} \\
(0.064)\end{array}$ & $\begin{array}{l}0.444^{* * *} \\
(0.067)\end{array}$ & $\begin{array}{l}0.434^{* * *} \\
(0.069)\end{array}$ & $\begin{array}{c}0.403^{* * *} \\
(0.063)\end{array}$ & $\begin{array}{c}0.384^{* * *} \\
(0.066)\end{array}$ \\
\hline $\begin{array}{l}\text { M2 money } \\
\text { supply }\end{array}$ & $\begin{array}{l}-0.163^{* *} \\
(0.063)\end{array}$ & $\begin{array}{c}-0.249^{* * *} \\
(0.058)\end{array}$ & $\begin{array}{c}-0.246^{* * *} \\
(0.056)\end{array}$ & $\begin{array}{c}-0.256^{* * *} \\
(0.061)\end{array}$ & $\begin{array}{c}-0.248^{* * *} \\
(0.062)\end{array}$ & $\begin{array}{c}-0.246^{* * *} \\
(0.056)\end{array}$ & $\begin{array}{c}-0.227^{* * *} \\
(0.056)\end{array}$ \\
\hline $\begin{array}{l}\text { Stock market } \\
\text { liquidity }\end{array}$ & $\begin{array}{l}0.261^{\text {**** }} \\
(0.020)\end{array}$ & $\begin{array}{l}0.264^{* * * *} \\
(0.021)\end{array}$ & $\begin{array}{l}0.264^{* * * *} \\
(0.021)\end{array}$ & $\begin{array}{c}0.269^{* * *} \\
(0.021)\end{array}$ & $\begin{array}{c}0.268^{* * * *} \\
(0.021)\end{array}$ & $\begin{array}{c}0.262^{* * * *} \\
(0.021)\end{array}$ & $\begin{array}{c}0.252^{\text {**** }} \\
(0.019)\end{array}$ \\
\hline Inflation & $\begin{array}{c}-1.175^{* * *} \\
(0.108)\end{array}$ & $\begin{array}{c}-1.157^{* * *} \\
(0.106)\end{array}$ & $\begin{array}{c}-1.158^{* * *} \\
(0.108)\end{array}$ & $\begin{array}{c}-1.141^{* * *} \\
(0.106)\end{array}$ & $\begin{array}{c}-1.131^{* * *} \\
(0.105)\end{array}$ & $\begin{array}{c}-1.210^{* * *} \\
(0.109)\end{array}$ & $\begin{array}{c}-1.169^{* * *} \\
(0.111)\end{array}$ \\
\hline vnD_X & $\begin{array}{c}-4.137^{* * *} \\
(1.138)\end{array}$ & $\begin{array}{c}-0.546^{* * *} \\
(0.078)\end{array}$ & $\begin{array}{c}-2.453^{* * *} \\
(0.403)\end{array}$ & $\begin{array}{c}-0.149^{* * *} \\
(0.021)\end{array}$ & $\begin{array}{c}-0.177^{* * *} \\
(0.025)\end{array}$ & $\begin{array}{c}-1.034^{* * *} \\
(0.224)\end{array}$ & $\begin{array}{c}-1.019^{* * *} \\
(0.226)\end{array}$ \\
\hline Constant & $\begin{array}{l}11.224 \\
(7.909)\end{array}$ & $\begin{array}{c}8.482 \\
(8.447)\end{array}$ & $\begin{array}{c}8.880 \\
(8.333)\end{array}$ & $\begin{array}{c}7.144 \\
(8.916)\end{array}$ & $\begin{array}{c}6.644 \\
(8.727)\end{array}$ & $\begin{array}{l}9.355^{* *} \\
(8.037)\end{array}$ & $\begin{array}{c}9.651 \\
(7.550)\end{array}$ \\
\hline Obs. & 396 & 396 & 396 & 396 & 396 & 396 & 396 \\
\hline
\end{tabular}




\begin{tabular}{lccccccc}
\hline $\begin{array}{l}\text { No. of instru- } \\
\text { ments }\end{array}$ & 34 & 34 & 34 & 34 & 34 & 34 & 34 \\
\hline No. of groups & 36 & 36 & 36 & 36 & 36 & 36 & 36 \\
\hline AR(2) test & 0.233 & 0.250 & 0.248 & 0.259 & 0.259 & 0.235 & 0.233 \\
\hline Sargan test & 0.612 & 0.280 & 0.280 & 0.279 & 0.281 & 0.278 & 0.290 \\
\hline Hansen test & 0.600 & 0.107 & 0.113 & 0.110 & 0.112 & 0.105 & 0.121 \\
\hline
\end{tabular}

Next, we explore the impact of institutional quality on stock market development in Vietnam. Similarly, we introduce a dummy variable for the case of Vietnam, and combine it with institutions variables, such as control of corruption (IN1), government effectiveness (IN2), political stability (IN3), regulatory quality (IN4), rule of law (IN5), and voice and accountability (IN6). These combinations generate six new variables to consist of $\mathrm{vnD}$ in 1 , vnD_in2, vnD_in3, vnD_in4, vnD_in5, and vnD_in6. Six models with each regression having one of these variables are sequentially estimated. The estimated results as summarized in Table 5 suggest that two indicators of institutional quality detected in Sub-Section 5.2 as determinants of stock market development in developing countries are the same as those for the case of Vietnam, being government effectiveness and rule of law. In Model 2 government effectiveness contributes significantly and positively to explaining stock market development in Vietnam. Furthermore, the effect of rule of law is found to be significant and positive in $\mathrm{Vi}$ etnam (Model 5).

However, differences exist between the circumstances of Vietnam and developing countries with respect to the effects of other indicators of institutional quality on stock market development. In Model 1 we find that the impact of control of corruption on stock market development in $\mathrm{Vi}$ etnam is positive and significant, confirming their tight linkage for the case of $\mathrm{Vi}$ etnam. An improvement in control of corruption will accordingly enhance stock market performance. The result of Model 3 shows that political stability has a significantly positive effect on stock market development in Vietnam, suggesting that political stability is also a key determinant of stock market development. Regulatory quality has a positive effect on Vietnam's stock market development (Model 4). This implies that good regulatory quality is crucial to the development of stock market in Vietnam because it reduces policy risk and stimulates demand for stocks. In Model 6 we find that the case of Vietnam witnesses the positive impact of voice and accountability on stock market development. This suggests that higher level of accountability derived from further encouragement of free media and transparency plays a major role in the development of Vietnam's stock market. 


\section{Table 5}

The effects of institutional quality on stock market development in Vietnam

Dependent variable: Stock market capitalization (\% of GDP)

\begin{tabular}{|c|c|c|c|c|c|c|}
\hline & $\begin{array}{l}\text { Model } 1 \\
\text { (vnD_in1) }\end{array}$ & $\begin{array}{c}\text { Model } 2 \\
\text { (vnD_in2) }\end{array}$ & $\begin{array}{c}\text { Model } 3 \\
\text { (vnD_in3) }\end{array}$ & $\begin{array}{c}\text { Model } 4 \\
\text { (vnD_in4) }\end{array}$ & $\begin{array}{l}\text { Model } 5 \\
\text { (vnD_in5) }\end{array}$ & $\begin{array}{l}\text { Model } 6 \\
\text { (vnD_in6) }\end{array}$ \\
\hline $\begin{array}{l}\text { Stock market capital. } \\
(-1)\end{array}$ & $\begin{array}{l}0.377^{* * *} \\
(0.041)\end{array}$ & $\begin{array}{l}0.394^{* * *} \\
(0.032)\end{array}$ & $\begin{array}{l}0.489^{* * *} \\
(0.060)\end{array}$ & $\begin{array}{l}0.388^{* * *} \\
(0.042)\end{array}$ & $\begin{array}{l}0.485^{* * *} \\
(0.039)\end{array}$ & $\begin{array}{l}0.267^{* * *} \\
(0.025)\end{array}$ \\
\hline Log GDP per capita & $\begin{array}{l}3.534^{* * *} \\
(1.198)\end{array}$ & $\begin{array}{l}2.977^{* * *} \\
(1.265)\end{array}$ & $\begin{array}{l}4.123^{* * *} \\
(1.343)\end{array}$ & $\begin{array}{l}2.254^{* *} \\
(0.965)\end{array}$ & $\begin{array}{l}2.250^{*} \\
(1.213)\end{array}$ & $\begin{array}{l}2.898^{* * *} \\
(0.742)\end{array}$ \\
\hline Domestic investment & $\begin{array}{l}-0.049 \\
(0.086)\end{array}$ & $\begin{array}{l}-0.053 \\
(0.069)\end{array}$ & $\begin{array}{c}0.016 \\
(0.072)\end{array}$ & $\begin{array}{l}-0.126 \\
(0.093)\end{array}$ & $\begin{array}{l}-0.134^{* *} \\
(0.050)\end{array}$ & $\begin{array}{c}-0.104 \\
(0.0118)\end{array}$ \\
\hline $\begin{array}{l}\text { Foreign direct in- } \\
\text { vestment }\end{array}$ & $\begin{array}{c}0.025 \\
(0.186)\end{array}$ & $\begin{array}{l}-0.077 \\
(0.116)\end{array}$ & $\begin{array}{c}0.106 \\
(0.381)\end{array}$ & $\begin{array}{l}-0.022 \\
(0.146)\end{array}$ & $\begin{array}{l}-0.154 \\
(0.109)\end{array}$ & $\begin{array}{l}-0.011 \\
(0.199)\end{array}$ \\
\hline Domestic credit & $\begin{array}{l}0.541^{* * *} \\
(0.068)\end{array}$ & $\begin{array}{l}0.232^{* * *} \\
(0.054)\end{array}$ & $\begin{array}{l}0.300^{* * *} \\
(0.103)\end{array}$ & $\begin{array}{l}0.470^{* * *} \\
(0.064)\end{array}$ & $\begin{array}{l}0.295^{* * *} \\
(0.070)\end{array}$ & $\begin{array}{l}0.638^{* * *} \\
(0.100)\end{array}$ \\
\hline M2 money supply & $\begin{array}{c}-0.314^{* * *} \\
(0.066)\end{array}$ & $\begin{array}{l}-0.159^{* * *} \\
(0.043)\end{array}$ & $\begin{array}{l}-0.201^{* *} \\
(0.081)\end{array}$ & $\begin{array}{c}-0.266^{* * *} \\
(0.062)\end{array}$ & $\begin{array}{l}-0.158^{* * *} \\
(0.049)\end{array}$ & $\begin{array}{l}-0.465^{* * *} \\
(0.096)\end{array}$ \\
\hline $\begin{array}{l}\text { Stock market liquid- } \\
\text { ity }\end{array}$ & $\begin{array}{l}0.193^{* * *} \\
(0.043)\end{array}$ & $\begin{array}{l}0.249^{* * *} \\
(0.018)\end{array}$ & $\begin{array}{l}0.234^{* * *} \\
(0.022)\end{array}$ & $\begin{array}{l}0.229^{* * *} \\
(0.039)\end{array}$ & $\begin{array}{l}0.066^{* * *} \\
(0.015)\end{array}$ & $\begin{array}{l}0.311^{* * *} \\
(0.025)\end{array}$ \\
\hline Inflation & $\begin{array}{c}-1.105^{* * *} \\
(0.133)\end{array}$ & $\begin{array}{c}-1.007^{* * *} \\
(0.139)\end{array}$ & $\begin{array}{c}-0.995^{* * *} \\
(0.245)\end{array}$ & $\begin{array}{c}-1.077^{* * *} \\
(0.114)\end{array}$ & $\begin{array}{c}-0.871^{* * *} \\
(0.111)\end{array}$ & $\begin{array}{c}-1.151^{* * *} \\
(0.084)\end{array}$ \\
\hline Institutional quality & $\begin{array}{l}-4.794^{*} \\
(2.518)\end{array}$ & $\begin{array}{l}8.222^{* * *} \\
(2.666)\end{array}$ & $\begin{array}{l}-6.508^{* *} \\
(2.630)\end{array}$ & $\begin{array}{c}0.488 \\
(2.204)\end{array}$ & $\begin{array}{l}6.227^{* * *} \\
(2.548)\end{array}$ & $\begin{array}{l}-0.987 \\
(2.327)\end{array}$ \\
\hline $\begin{array}{l}\text { VN institutional } \\
\text { quality }\end{array}$ & $\begin{array}{c}26.011^{* * * *} \\
(3.041)\end{array}$ & $\begin{array}{c}34.937^{* * *} \\
(8.574)\end{array}$ & $\begin{array}{c}1.055^{*} \\
(14.732)\end{array}$ & $\begin{array}{c}22.609^{* * * *} \\
(4.399)\end{array}$ & $\begin{array}{c}24.593^{* * * *} \\
(4.807)\end{array}$ & $\begin{array}{c}11.888^{* * *} \\
(3.086)\end{array}$ \\
\hline Constant & $\begin{array}{c}-3.952 \\
(10.525)\end{array}$ & $\begin{array}{c}6.777 \\
(10.633)\end{array}$ & $\begin{array}{l}-14.650 \\
(13.314)\end{array}$ & $\begin{array}{c}8.591 \\
(9.185)\end{array}$ & $\begin{array}{c}10.306 \\
(11.097)\end{array}$ & $\begin{array}{l}12.449^{*} \\
(6.236)\end{array}$ \\
\hline Obs. & 360 & 396 & 396 & 360 & 396 & 396 \\
\hline No. of instruments & 33 & 36 & 28 & 33 & 36 & 36 \\
\hline No. of groups & 36 & 36 & 36 & 36 & 36 & 36 \\
\hline
\end{tabular}




\begin{tabular}{lllllll}
\hline AR(2) test & 0.207 & 0.234 & 0.175 & 0.220 & 0.160 & 0.311 \\
\hline Sargan test & 0.275 & 0.316 & 0.357 & 0.222 & 0.130 & 0.112 \\
\hline Hansen test & 0.285 & 0.217 & 0.198 & 0.264 & 0.224 & 0.216 \\
\hline
\end{tabular}

Notes: ${ }^{* * *},{ }^{* *}$ and ${ }^{*}$ denote significance at $1 \%, 5 \%$, and $10 \%$ respectively; standard deviation is in parentheses.

\section{Conclusion and policy implications}

This study investigates macroeconomic and institutional determinants of stock market development in developing countries, using a panel of 36 countries for the period of 2003-2014. For another, it explores determinants of stock market development in Vietnam and then compares them with those in developing countries in order to well understand the case of Vietnam.

Regarding macroeconomic factors in developing countries, the study finds interesting results. First, economic growth, domestic credit, and stock market liquidity are positive determinants of the development of the stock market in developing countries. We document that: (i) initial economic growth is critical to stock market performance; (ii) an improvement in domestic credit to private sector promotes stock market development, implying that there exists a complementary relationship between banking sector and stock market in developing countries; and (iii) the more liquid the stock market, the larger the amount of savings toward stock markets. Second, the association between money supply and stock market development is negative, sug- gesting that further sound money and interest rate policy should be adequately adopted to support the growth of the market. Third, institutional factors, such as government effectiveness and rule of law, impact significantly and positively on stock market development, implying that these factors are crucial to the development of stock market in developing countries. Meanwhile, corruption control and political stability are found to have a significant and negative effect on determining stock market development.

There are considerable differences in explaining the development of stock market between developing countries and $\mathrm{Vi}$ etnam. First, the impacts of macroeconomic factors, such as economic growth, domestic investment, foreign direct investment, domestic credit, broad money supply, stock market liquidity, and inflation are significant but negative on the development of stock market in Vietnam. Nevertheless, the effects of domestic investment and foreign direct investment are insignificant, whereas those of economic growth and stock market liquidity are significant and positive for the case of developing countries. These findings suggest that Vietnam stock market is still an emerging market 
and at its early stage of development; therefore, to develop the stock market Vietnamese government should adopt sound policies that stimulate its sustainable growth by improving overall economic growth, domestic investment, and FDI. Monetary policy should target inflation to support the process of stock market development. Second, all institutional factors, such as control of corruption, government effectiveness, political stability, regulatory quality, rule of law, and voice and accountability are positive determinants of the development of stock market in Vietnam, which implies that well-established institutions are crucial to promoting demand for stocks and improving Vietnam's stock market performance. Vietnamese government should push institutional reforms, especially financial market institutions to reduce asymmetric information, risks, and transactional cost, and to facilitate the progress

\section{References}

Abdul Malik, I., \& Amjad, S. (2013). Foreign direct investment and stock market development in Pakistan. Journal of International Trade Law and Policy, 12(3), 226-242.

Acquah-Sam, E. (2016). Determinants of capital market development in Ghana. European Scientific Journal, 12(1), 251-270.

Anderson, T. W., \& Hsiao, C. (1982). Formulation and estimation of dynamic models using panel data. Journal of Econometrics, 18(1), 47-82.

Arellano, M., \& Bond, S. (1991). Some tests of specification for panel data: Monte Carlo evidence and an application to employment equations. The Review of Economic Studies,
58(2), 277-297.

Asongu, S. A. (2012). Government quality determinants of stock market performance in African countries. Journal of African Business, 13(3), 183-199.

Ayaydın, H., \& Baltacı, N. (2013). Corruption, banking sector, and stock market development: A panel data analysis. European Journal of Research on Education, Special Issue: Human Resource Management, 94-99.

Ben Naceur, S., Ghazouani, S., \& Omran, M. (2007). The determinants of stock market development in the Middle-Eastern and North African region. Managerial Finance, 33(7), 477-489.

Batten, J., \& Vo, X. V. (2014). Liquidity and return relationships in an emerging market. Emerging Markets Finance and Trade, 50(1), 127-143.

Biswas, R., \& Ofori, E. (2015). Democracy and stock market development: The African experience. Overlaps of Private Sector with Public Sector around the Globe (Research in Finance, Volume 31) Emerald Group Publishing Limited, 31, 65-86.

Blundell, R., \& Bond, S. (1998). Initial conditions and moment restrictions in dynamic panel data models. Journal of Econometrics, 87(1), 115-143.

Blundell, R., Bond, S., \& Windmeijer, F. (2001). Estimation in dynamic panel data models: Improving on the performance of the standard GMM estimator. Nonstationary Panels, Panel Cointegration, and Dynamic Panels, 15, 53-91.

Cherif, M., \& Gazdar, K. (2010). Macroeconomic and institutional determinants of stock market development in MENA region: New results from a panel data analysis. International Journal of Banking and Finance, 7(1), 139-159.

Claessens, S., Klingebiel, D., \& Schmukler, S. (2001). FDI and stock market development: Complements or substitutes? World Bank Working Paper. 
Dzhumashev, R. (2014). Corruption and growth: The role of governance, public spending, and economic development. Economic Modelling, 37, 202-215.

El-Nader, H. M., \& Alraimony, A. D. (2013). The macroeconomic determinants of stock market development in Jordan. International Journal of Economics and Finance, 5(6), 91103.

Evrim-Mandaci, P., Aktan, B., Gumus, G. K., \& Tvaronavičiene, M. (2013). Determinants of stock market development: Evidence from advanced and emerging markets in a long span. Business: Theory and Practice/Verslas: Teorija ir Praktika, 14(1), 5156.

Jeffus, W. (2004). FDI and stock market development in selected Latin American countries. International Finance Review, 5, 35-44.

Gani, A., \& Ngassam, C. (2008). Effect of institutional factors on stock market development in Asia. American Journal of Finance and Accounting, 1(2), 103-120.

Garcia, V. F., \& Liu, L. (1999). Macroeconomic determinants of stock market development. Journal of Applied Economics, 2(1), 29-59.

Goldsmith, A. A. (1987). Does political stability hinder economic development? Mancur Olson's theory and the Third World. Comparative Politics, 19(4), 471-480.

$\mathrm{Ng}$, A., Ibrahim, M. H., \& Mirakhor, A. (2016). Does trust contribute to stock market development? Economic Modelling, 52, 239-250.

Nickell, S. (1981). Biases in dynamic models with fixed effects. Econometrica: Journal of the Econometric Society, 1417-1426.

Phan, D. N., \& Vo, T. H. H. (2013). Determinants of stock market development in Southeast Asian countries. Journal of Economics and Development, 14(1), 101.

Quartey, P., \& Gaddah, M. (2007). Long run determinants of stock market development in Ghana. Journal of African Business, 8(2), 105-125.
Raza, A., Iqbal, N., Ahmed, Z., Ahmed, M., \& Ahmed, T. (2012). The role of FDI on stock market development: The case of Pakistan. Journal of Economics and Behavioral Studies, 4(1), 26-33.

Raza, S. A., \& Jawaid, S. T. (2014). Foreign capital inflows, economic growth and stock market capitalization in Asian countries: An ARDL bound testing approach. Quality \& Quantity, 48(1), 375-385.

Raza, S. A., Jawaid, S. T., Afshan, S., \& Karim, M. Z. A. (2015). Is stock market sensitive to foreign capital inflows and economic growth? Evidence from Pakistan. Journal of Chinese Economic and Foreign Trade Studies, 8(3), 142-164.

Roodman, D. (2009). How to do xtabond2: An introduction to difference and system GMM in Stata. Stata Journal, 9(1), 86-136.

Shahbaz, M., Rehman, I. U., \& Afza, T. (2015). Macroeconomic determinants of stock market capitalization in an emerging market: Fresh evidence from cointegration with unknown structural breaks. Macroeconomics and Finance in Emerging Market Economies, $9(1), 1-25$.

Soto, M. (2009). System GMM estimation with a small sample. Barcelona Economics Working Paper Series No. 395.

Swaleheen, M. (2011). Economic growth with endogenous corruption: An empirical study. Public Choice, 146(1-2), 23-41.

Vo, X. V. (2015). Foreign ownership and stock return volatility: Evidence from Vietnam. Journal of Multinational Financial Management, 30, 101-109.

Yartey, C. A. (2008). The determinants of stock market development in emerging economies: Is South Africa different? IMF Working Paper. 2008 International Monetary Fund.

Yartey, C. A. (2010). The institutional and macroeconomic determinants of stock market development in emerging economies. Applied Financial Economics, 20(21), 1615-1625. 